\title{
Quiasmática convivialidade em Raul Brandão e Maria Gabriela Llansol
}

\author{
Lígia Bernardino \\ Universidade do Porto
}

Resumo: Duas perceções convergentes na reprovação da sociedade dos homens segundo a ordem estabelecida resultam em modos divergentes de alterar a configuração do mundo. Há utopia em Maria Gabriela Llansol na radical idealização de um mundo des-hierarquizado, ao ponto de aceitar a inclusão de animais e restante vivo na tomada de decisões sobre o mundo. Há distopia em Raul Brandão no desfiar de vidas em sombra que nem no sonho encontram aplacação para um sofrimento permanente. Os momentos de convívio e de alimento (ou sua ausência) apresentam-se nos dois autores como topoi significativos para o entendimento das suas formas de ler o mundo através da literatura.

Palavras-chave: Raul Brandão, Maria Gabriela Llansol, distopia, utopia

Abstract: Two convergent perceptions in undermining the established order of the city eventually suggest divergent ways of changing the state of affairs in the world. There is utopia in Maria Gabriela Llansol's radicalization of an ideal world free of hierarchies, up to the limit of accepting the inclusion of animals and the rest of the living beings in the decision making process. There is dystopia in Raul Brandão's work, as he fictionalizes characters living in the shadows, hoping for dreams that will never soothe their pain. Conviviality and food (or its absence) are meaningful topoi to the understanding of the way these two authors read the world through literature.

Keywords: Raul Brandão, Maria Gabriela Llansol, dystopia, utopia 


\author{
A terra - disse ele -, tem pele, e essa pele tem doenças. \\ Uma dessas doenças, por exemplo, chama-se «homem» \\ Friedrich Nietzsche,
}

Assim Falava Zaratustra (1888: 180)

Servem-se ao mesmo tempo o príncipe, o pontífice, os traníboros, os embaixadores e os estrangeiros Thomas More,

Utopia (1516: 99)

\title{
1. Movimento de utopias e distopias
}

Entre uma utópica proposta de reorientação radical e uma distópica focalização na miséria, Maria Gabriela Llansol, no primeiro caso, e Raul Brandão, no segundo, introduzem nas suas obras provocações extremas como forma de questionamento da condição e das escolhas humanas. Há, nas obras destes autores, momentos em que a partilha conforta vivências, por mais desesperadas que estas demonstrem ser. 0 entendimento patente nas figuras ${ }^{1}$ de Maria Gabriela Llansol, cuja emergência ocorre na trilogia Geografia de Rebeldes, publicada entre 1977 e 1984, e nas personagens de Raul Brandão, em O Gebo e a Sombra, peça de teatro em quatro atos publicada pela primeira vez em 1923, mas laboriosamente trabalhada ao longo de mais de vinte anos, encontra no alimento partilhado forma privilegiada de se concretizar. Recusando um discurso abonatório e de aceitação da ordem estabelecida, os dois autores optam por uma abordagem em que os mais desfavorecidos surgem com o protagonismo que a História lhes nega, assim os enobrecendo para além da desgraça. 
Dar comida a gatos vadios, como acontece em A Restante Vida, segundo volume da trilogia referida de Maria Gabriela Llansol, publicado em 1983; fazer café para partilhá-lo com os convivas numa esconsa casa em dias invernais, como acontece em $O$ Gebo e a Sombra, de Raul Brandão, revelam pequenos gestos que alimentam o estreitamento de laços e, desse modo, aventam a possibilidade de reconversão de uma sociedade tomada como implacável. Estas isotopias, indiciadoras de práticas que fomentam um intercâmbio afetivo, assumem particular importância quando a miséria e a marginalidade parecem tomar conta das figuras e personagens criadas. Não se trata apenas de suscitação de empatias, mas de gestos que desafiam um ambiente hostil.

Segundo Roland Barthes, "o pormenor alimentar excede a significação, e o suplemento enigmático do sentido (da ideologia)" (1971: 125). Partindo deste pressuposto, analisar nos autores aqui abordados a alimentação implica interpretá-la enquanto índice: através das atitudes das personagens envolvidas, descobrem-se posicionamentos éticos, existenciais, comportamentais. Descobrem-se ainda os contrastes entre os momentos disfóricos vivenciados e as utopias desejadas ou pressentidas.

Parasceve, obra de Maria Gabriela Llansol publicada em 2001, propõe uma nova ordem do planeta que se distancie de perspetivas antropocêntricas, submetendo a supremacia da espécie humana a um processo de des-hierarquização. 0 extrato seguinte revela o júbilo face à construção de um utópico novo mundo:

há sempre posta, no Grande Maior, a mesa de um banquete e todos os vivos ditos e por dizer, desde as cadeiras aos copos, desde as folhas aos ramos, desde os personagens às suas pregas de invenção, a servem de puzzles e de ironias. E compreendo intuitivamente que assim seja. Não está o espaço cheio de iguarias e de imprevisíveis?

O que sinto, sobretudo, no espaço é o entusiasmo. (Llansol 2001: 75)

O entusiasmo sentido neste espaço inusitado resulta de uma utopia: face aos desmandos da humanidade, à sua propensão para os mais nefastos cataclismos, nesta obra, Llansol propõe uma forma alternativa de co-habitação, celebrada pela formação de uma criança-ruah, espécie de asa ou criança-espírito que resulta da fusão de espécies diversas, 
incluindo o homem, do qual herda a consciência. A concretização deste ser, conseguida sob a proteção do Grande Maior, plátano gigante que funciona como um organismo tornado habitat de todos os vivos, é festejada em júbilo num banquete onde as espécies se indistinguem. Sem vencedores nem vencidos, assumindo um total anonimato, a partilha do banquete resulta na celebração de alternativas ao discurso do poder, ideia prevalecente desde o início da obra de Llansol.

O banquete llansoliano celebra a despossessão, não só pelo anonimato e pela diversidade de espécies que nele intervêm, como também pelo irrepresentável patente na figura da criança-ruah. Como defende Silvina Rodrigues Lopes a propósito da obra llansoliana, “o inapresentável é o impossível que nos toma permitindo-nos ir além do que podemos ir, mostrando-nos que somos para além do que conhecemos de nós, diferentes do todo que nos imaginamos ser" (1988: 8). A denegação do antropocentrismo patente na obra llansoliana permite atingir o mais além sugerido por esta ensaísta, de que o jubiloso banquete é celebração.

Concomitante ao inapresentável, nota-se em Llansol a irrisão dos senhores, daqueles que fizeram a História instituída, mas que, pela sua ação, foram responsáveis por atrocidades ocorridas ao longo dos séculos, como Geografia de Rebeldes o explicita. Paralelamente à recuperação constante que esta autora faz de filósofos e místicos (Nietzsche, Spinoza, Eckhart ou João da Cruz são disso exemplo), a recorrência da batalha de Frankenhausen, ocorrida em 1523, na Alemanha, entre camponeses e senhores, tendo os primeiros sido dizimados, atesta a prevalência de um belicismo que acompanha o ser humano e que o século XX, através sobretudo do Holocausto nazi, levou ao extremo. A utopia de um ser como a criança-ruah indicia um esperançoso caminho inverso a tais atrocidades, donde a celebração jubilosa no Grande Maior.

"Parasceve" é um termo de raiz judaica que significa a véspera da Páscoa, tempo de preparação festiva que assinala a Primavera, ou seja, o renascimento. Na obra homónima de Llansol, ao exaltar a abertura de um novo ciclo de existência, a alusão pascal contraria a tradição cristã que assinala a morte de Cristo; já Raul Brandão, por paradoxo, no texto 
memorialístico denominado "O silêncio e o lume", converte a ceia de Natal, momento que celebra o nascimento de Cristo, numa pungente reflexão escatológica acerca da morte:

Dois vivos e tantos mortos sentados à roda desta mesa que veio de meu pai, foi de meu avô e pertenceu já a outras gerações desconhecidas, mas que estão aqui também comigo, escutando e sorrindo, enquanto as pinhas se transformam em flores maravilhosas e as vides que plantei se reduzem a cinzas!... Nunca estive tão acompanhado como hoje nesta ceia religiosa de fantasmas, numa comunhão de saudade e de lágrimas, e sentindo que cada Natal volvido mais me aproxima dos mortos. Aumenta o silêncio húmido que nos isola do mundo. (Brandão 1925: 39)

Não há, nesta consoada, senão uma sombra do que a época natalícia pressupõe: os cabelos estão brancos, as cadeiras vazias, os antepassados regressam em anamnese, a expectativa cifra-se apenas num reencontro post mortem. 0 alimento desvanece-se, ao mesmo tempo que os laços entre as almas se fortalecem. 0 surpreendente sujeito composto inicial converte a mesa num lugar metafísico, zona de interseção de tempos, onde a comunicação das almas é possível. Uma forma de utopia, pois: a possibilidade de entendimento supra-individual, longe do mundo - depreende-se que dos vivos -, atenua a imagem espectral que este extrato suscita. No mesmo texto, Brandão acrescenta: “o importante é a comunicação de alma para alma" (1925: 41), e isso a ceia de Natal proporciona.

As imagens grotescas que povoam a obra de Raul Brandão estendem-se metonimicamente das personagens à sua alimentação. "Balanço à vida", texto publicado postumamente em 1933 nas Memórias, tomo III, destaca a figura de um caseiro do autor velho e indigente, bem como da sua família. A descrição física e comportamental tanto dele quanto da sua esposa é pouco abonatória. No entanto, verifica-se um enobrecimento destas duas figuras no momento em que comem:

Ele é bronco e solene como os bois, ela é esperta e velhaca. A senhora Rosa, que fala fanhoso, todo o dia resmunga e diz das outras que não carregam nem lavram:

- É uma mulher que não sai detrás das panelas.

Levam horas a comer. Comer, para o lavrador, que sabe o que lhe custa o pão, é um acto religioso. 
Moem e remoem devagar o caldo e a broa, com o respeito de nossos pais diante da mesa posta. (Brandão 1933: 37)

A diferença entre a ceia de Natal numa casa de família burguesa e uma refeição de lavradores pobres é nítida. Há, todavia, uma aproximação utópica em termos de reverência religiosa face à "mesa posta", como o autor refere nesta citação. Apesar das divergências que este casal de pobres manifesta ter, quando à mesa, o convívio ameno surge e impõe-se o respeito, assim se extraindo a vida à banalidade dos dias. A forma como começa este texto memorialístico demonstra-o categoricamente: "ou a vida é um acto religioso - ou um acto estúpido e inútil" (35). A banal circularidade dos dias encontra à mesa a sua redenção.

Pensando nos Evangelhos, a ceia descrita por Raul Brandão destaca-se como elemento de valor simbólico estruturante: mais do que celebração, ela produz a comunhão das almas em torno da mesma figura religiosa, dispostas à partilha de uma ética comum. Segundo Jacques Derrida, independentemente da religião, o que está em causa é "um invencível desejo de justiça" (1996: 30). Ora, as refeições comuns enquanto forma de convívio e de conduta ética coletiva acompanham a evolução humana pelo menos desde a Grécia Antiga, designadamente através de Platão. Segundo os ensaístas Michael Jackson e Damian Grace, "for Plato, commensality is a means to virtue" (2014: 21), motivo pelo qual a refeição comum pode interpretar-se como utópica forma de prover a uma sociedade equilibrada, justa, equitativa.

Curiosamente, nos dois autores aqui abordados, estes valores são mais claramente expressos nas refeições comuns de Llansol do que de Brandão: os festejos no Grande Maior, na sua radical multiplicidade de espécies, surgem como mais virtuosos do que as nostálgicas e pobres refeições descritas por Raul Brandão. De novo um exercício quiasmático: se a obra de Llansol desafia constantemente a supremacia de uma "razão raciocinante" (Lopes 1988: 50), assim se distanciando de um ordenamento platónico enquanto ideal de sociedade, já Raul Brandão convoca a alegoria da caverna de Platão, ao mergulhar as suas personagens num mundo de sombras, que, contudo, apenas fomenta sonhos ilusórios. Como resultado, é em Llansol que uma verdadeira reconversão da 
existência se propõe, pois não se vislumbra em Raul Brandão uma escapatória para as suas personagens, retidas num desesperançado ciclo vicioso, ainda que reunidas em torno de uma mesa, na companhia cúmplice da família e de amigos.

Em Leis, uma das últimas obras de Platão, este filósofo aponta as virtudes das refeições comuns para preparar os soldados em tempos de paz, pois, na guerra, terão necessariamente de partilhar espaços e objetivos. O legislador de Creta tornou as refeições em comum obrigatórias, para condenar "the stupidity of the mass of men in failing to perceive that all are involved ceaselessly in a lifelong war against all States" (Platão, 1965: 7). Nem as figuras de Llansol, nem as personagens de Brandão escapam a um sentimento de ameaça face a um exterior adverso: vivem metaforicamente em estado de guerra permanente, facto este também verificável em contextos de convivialidade. Mas é nestes momentos que se alimentam os laços, como acontece sobretudo em Llansol, e se libertam os pensamentos mais negros, principalmente quando as personagens brandonianas expressam tentações de outro modo inconfessáveis.

Segundo o ensaísta Lyman Tower Sargent, mesmo a distopia tem um aspeto positivo: o diagnóstico do mal implica o desejo do bem, ou o sonho da existência desse bem. Talvez seja essa uma interpretação possível para a dolorosa empatia que os textos de Raul Brandão incitam ao convocarem os pobres. Afinal, a indigência em que vivem legitima comportamentos social e eticamente reprováveis, num desafio aos sentimentos platónicos de temperança, justiça e equilíbrio. A busca de uma sólida base de entendimento, logo, de pacificação e co-habitação entre os seres, está mais próxima de Llansol, mas esta renega uma exclusividade humana. Aquém de Platão; além de Platão: estes, respetivamente, os posicionamentos de Brandão e de Llansol nas suas utópicas formas de perceção do real.

\section{As reversões utópicas}

Raul Brandão apresenta as suas personagens entrincheiradas num universo distópico cuja linha de fuga, a existir, as impele numa direção distante do apaziguamento, acabando por voltar ao ponto de partida, num obsidiante eterno retorno. Em $O$ Gebo e a Sombra, o café com que as personagens repetidamente se confortam nas noites escuras de 
Inverno revela o enclausuramento num patamar da escala social que, por paradoxo, não as conforta, mas desperta para a miséria em que vivem. Já Maria Gabriela Llansol imprime ao seu texto uma rizomática escapatória, tendo em vista o alcance de conhecimento e entendimento capazes de superar uma sociedade cuja história se preenche de horrores. Sábio será quem conseguir abstrair-se dos atos mais simples e quotidianos, como cozinhar, para se assenhorear, não de bens materiais, mas espirituais. Lê-se n'O Livro das Comunidades:

O homem deve abdicar do poder e a mulher do homem, pensou a mulher que cozinhava na areia e era mestre na arte de pensar [...].

0 odor do que a mulher cozinhava começava a propagar-se pelo espaço até às franjas do deserto. Chás, legumes, cereais, carnes crestadas.

Enquanto cozinhava sobre as brasas, o mestre na arte de pensar experimentou o sentimento de ser rosa, de constantemente se abrir em pétalas e perfumes, de ser a dama onde a fome monstruosa se acaba [...]. (1977: 39)

O claro discurso antipoder no início deste excerto entrelaça-se com o ato de cozinhar, como se ação e pensamento se harmonizassem e, juntos, alimentassem a utopia de uma sociedade mais justa e radicalmente des-hierarquizada, ao ponto de abranger todo o vivo, animal ou não. Na obra de Llansol, o caminho é o da permanente regeneração, mesmo que tal implique metamorfoses inesperadas, como o que acontece a esta mulher, que se converte em pétalas de rosa soltas ao ar do deserto. As visões geram pensamentos; juntos criam utopias, face à constatação de que a fome existe, donde a imperiosa necessidade de uma transformação. Enquanto metáfora, a fome revela a existência de uma sociedade injusta, portanto, a negar e reconverter. A ressonância de Nietzsche (figura insistentemente convocada por Llansol) é clara, pela necessidade de instauração de novos valores e que, conforme Gilles Deleuze explica a propósito das metamorfoses nietzschianas, incita “novos princípios de avaliação” (1965: 9).

Na obra de Raul Brandão, são frequentes os momentos em que as personagens procedem a avaliações das suas vidas, numa atitude de "fazer vir à tona a verdade abismada 
do ser", conforme defende a ensaísta Maria João Reynaud (2000: 267). Em O Gebo e a Sombra, a fome acaba por ditar a tentação e a desgraça das personagens, como acontece com João, filho do Gebo, que vê nesse facto a justificação para uma vida de crime:

João: Mas antes a cadeia! Na cadeia também se come pão. Antes morrer do que viver sepultado. Doroteia: Filho!

João: Do que isto! Antes morrer. Deixem-me falar... Um crime qualquer o pratica, crimes maiores se fazem todos os dias, de mentira e de abjecção. Crimes maiores, e às vezes é um nada que nos impede de matar... $[\ldots]$

Um homem que esteve na cadeia não pede esmola. Sabe tudo da vida e da morte. Vejo a rua deserta e vejo-me decidido a não me deixar morrer de fome. De fome!... Um momento de angústia e de desespero... À roda tudo negro... Não era só o negrume da noite e da parede enorme a que me tinha encostado... Maior, mais espesso o negrume da minha alma. (Brandão 1923: 86)

Nietzsche, em Assim Falava Zaratustra, propõe uma reconversão subversiva: "deixaivos derribar para volverdes à vida e que de vós se assenhoreie a virtude!” (2010: 182). Também João se deixa derribar, como acontece com Gebo, o seu pai, no final desta peça. Porém, no meio da desesperança, não se nota o gérmen da reconversão, nem sequer o crime acaba por trazer qualquer alento. A utopia, em Raul Brandão, distancia-se do destino das personagens, dada a instrumentalidade que preside à sua conceção: mostrar a ruína das suas vidas para incitar mudanças políticas, sabendo que a virtude não está ao alcance dessas personagens.

Ainda segundo Reynaud, “o simbolismo visionário de Raul Brandão segue a via de um expressionismo abstractizante, através do qual se insinua o mistério do ser" (2000: 267). A clarividência do discurso de João, no excerto acima transcrito, não o regenera, mas mergulha-o ainda mais na culpa, por mais que não admitida. 0 negrume em que se sente metaforiza a impossibilidade de escapatória da miséria, mesmo que esta esteja mascarada pela posse dos produtos roubados. Para além de física, há a miséria moral, e essa afunda as personagens - João, como Gebo - num abismo irreversível e grotesco.

Nas suas Memórias, o autor refere que, num determinado momento da sua vida, sentia estar a despenhar-se "num mundo de espectros" (1925: 43). Nessa altura, "a face 
humana meteu-me medo pelo que nela descobria de repulsivo e de grotesco" (ibidem). Ora, o expressionismo de $O$ Gebo e a Sombra demonstra toda a conflitualidade latente da obra de Raul Brandão, cujo sentimento de comiseração pelas personagens descritas está impregnado de repulsa. 0 final da peça, com o Gebo a rir sarcasticamente após sair da prisão, mas para sempre convertido ao crime, exemplifica a contradição. Nessa altura, não pede café, bebida que acompanha os serões de trabalho em casa; antes, repete: "não há por aí nada que se beba?" (1923: 115; 116). A embriaguez sugerida agora é outra.

Llansol radicaliza os seus posicionamentos contrários ao antropocentrismo através da aproximação ao animal não-humano; Raul Brandão convoca o grotesco para acentuar um estado de miséria que legitima pensamentos e atitudes moralmente questionáveis, senão mesmo torpes. Escreve o autor em Húmus, pela voz de um ladrão:

Morreu tísica, morreu-me à fome e não lhe pude valer! Fiz-me depois ladrão. Deixemos os mortos... Uma madrugada fui de prego em prego. Tinha despido o casaco para o pôr no prego. À porta de um estava um cavalo à carroça, com a cabeça metida numa seira, a comer. 0 que eu invejei aquele cavalo! Morreu-me. Foi nesse dia que me fiz ladrão. (1917: 123)

A criança-ruah de Parasceve resulta da reconversão de um esqueleto de uma criança que vem a ser sepultada junto a uma árvore, donde a sua transformação num ser híbrido, que resulta do húmus. Também Raul Brandão propõe uma reconversão, mas aqui claramente de foro moral: a opção pelo crime é um ato humano consciente, mas apresentado enquanto forma reativa a uma inapelável miséria, de que a fome é o índice mais evidente. Na sua análise de Húmus, Pedro Eiras questiona se este livro será "irónico ou literal, ou ainda irónico e literal" (2005: 145). O exercício hermenêutico do excerto acima viabiliza leituras psicanalíticas ou sociológicas: há uma obsessão latente que se denota na persistência de um momento traumático, e isso justificará a vida de crime, via única de apaziguamento da dor. Por outro lado, a miséria sem saída gera opções de marginalidade.

Mas será esta uma leitura literal, resultante de um processo de empatia com o infortúnio? Ou haverá neste extrato uma ironia que mascara a imoralidade de uma vida dedicada ao crime? Estará esta personagem apenas a camuflar a dupla culpa sentida por 
não ter conseguido salvar a filha e pela prática dos roubos? Talvez não haja uma resposta unívoca para estas questões. No entanto, o topos da alimentação - mais precisamente, da sua ausência - serve de grande significante que se abre à explicitação não da miséria enquanto forma de vida, mas da possibilidade de reconversão paradoxalmente irredimível: literal ou irónica, a culpa prevalece.

No entanto, mesmo resultando em irrisão, houve uma tentativa, eventualmente utópica, de mudança. Sargent afirma que "there are always alternative utopias" (2005: 5), mediante os condicionalismos de uma época, de um pensamento, considerando que "utopian thinking is essential for our social, political, and psychological health, but, like everything else, utopian thinking is time- and place- bound. One model does not fit all" (4). Ora, nesse sentido, a busca de reconversão que o ladrão assume deriva de uma utopia: a de que seria ainda possível transmutar-se de uma vida de fome para uma vida confortável, assim redimindo a memória da filha. 0 mesmo poderia ser dito a propósito de Gebo: o seu contexto induz um estilo de vida mergulhado na precariedade e a sua escolha final resulta das circunstâncias de todo o percurso vivido.

Ainda segundo Pedro Eiras, “a obra de Raul Brandão compara o movimento de classes populares contra elites económico-sociais com a epifania divina, numa ambígua indistinção, porém, entre purga curativa e mera catástrofe" (2005: 134). Como se de uma condenação se tratasse: nascer na miséria não permite enriquecimento ou ascensão na escala social. Por outras palavras, nascer na miséria fomenta o crime. Uma existência de miséria concede apenas a esperança transmitida pelo sonho. Antes de o seu filho aparecer e, em consequência, se revelar a vida de crime em que viveu, afirma Doroteia, a esposa de Gebo: "o que me vale é o que me resta de sonho" (1923: 75). Essa é a sua única utopia, pois, diz Gebo, “a vida é sempre a mesma coisa” (74).

O estaticismo presente em $O$ Gebo e a Sombra impele para a utopia do sonho, instigada ainda por rituais como os do café tomado para aquecer nos serões invernosos. Em Llansol, por seu turno, possibilidades metamórficas, como a transformação de Eckhart numa aranha ou o ato de Nietzsche ser tragado por um porco, nele se transformando, alimentam a utopia de um entendimento espiritual, apaziguador de tensões entre os 
homens e entre estes e o cosmos de que também eles fazem parte. Estas duas posições contrárias reforçam, contudo, um estado de inconformismo cujo limite será a utopia.

\section{Da disponibilização do comum}

Imersas no sonho, as personagens de Raul Brandão encontram a sua utopia: um nãolugar (tendo em conta a etimologia) que lhes permite sobreviver ao desespero, única forma de resistência à distopia do mundo em que efetivamente vivem. Doroteia exemplifica: vivendo na miséria, ignorando o destino do filho, só o sonho compensa uma existência indigente. N'A Restante Vida, obra de Maria Gabriela Llansol integrante da trilogia Geografia de Rebeldes e publicada em 1983, face à tragédia, a narradora concebe uma eutopia: um lugar bom, de aceitação do díspar e de cumplicidade. Este livro centra a sua ação na já aludida batalha de Frankenhausen. Vivem-se, portanto, perigosos momentos de tensão que culminam na morte de trinta mil camponeses em 1523, às mãos dos detentores do poder. Este é um acontecimento histórico factual, mas a interpretação literária presente neste livro revela uma desesperança em relação à capacidade humana de atingir a paz. Face a tal descrença, a voz narrativa volta-se para um lugar radical, para uma utopia capaz de transcender o humano:

O que se meditava passava-se ao nível do chão do pátio; estava-se para lá da noite embora fosse ainda o fim da tarde, a dar de comer a um gato branco que encontrara refúgio debaixo de um carro; tudo era luz azulada sobre as pedras; havia um gato aqui, outro além, o cão desorientado não sabia se correr, ladrar ou calar-se. Mas o gato magro e tímido, fusiforme, subira para a balaustrada com Fokouli, o nosso gato branco, onde se mantinha a uma certa distância. Eu via de baixo; deitada no chão em cima da esteira sentia-me uma filha da noite, queria viver com eles e entre eles, não queria voltar a ser nomeada pelos homens. Cada um deles me desejava. Sobretudo a carícia, mesmo antes da carne cortada aos bocados, talvez primeiro que tudo ouvir o nome da penetração de um tempo em que os homens, se assim continuarem, terão desaparecido.

Eu tinha a impressão de ouvir vozes, que o meu gato e o gato tímido me diziam: «desaparece connosco. Longa é a noite, deixa-te levar de casa, que já não é a de teus pais, para nossas terras». (1983: 64) 
A linearidade do relato e o modo convencional como as frases se sucedem contradizem o movimento sempre imprevisível que assola Geografia de Rebeldes. No entanto, a mensagem - a eutopia - aqui expressa surpreende pela simplicidade subversiva com que se afronta a ordem humana. A expressão "para lá da noite" transporta este registo para fora do reconhecível: o espaço é o da meditação e da marginalidade, que significa um distanciamento da ordem convencional dominada pelo homem. 0 apelo é de libertação, tal como expresso por João, o filho ladrão de Gebo, na peça $O$ Gebo e a Sombra. Nela, diz esta personagem: “abre a janela toda, deixa entrar a noite...” (Brandão 1923: 94). Ora, metaforicamente, trata-se da marginalidade de uma vida de crime. As sombras brandonianas coartam a possibilidade de redenção, ao contrário da noite llansoliana.

A inversão de todos os valores no excerto destacado de Llansol manifesta-se, desde logo, pelo plano de visão: a narradora observa os gatos "deitada no chão", enquanto estes circulam na balaustrada. A conclusão óbvia é a de que cabe aos gatos fazer uma proposta. São eles quem sugerem à narradora a possibilidade de uma realidade-outra e lhe criam o desejo de romper com o mundo humano, já que este está condenado à ruína, caso mantenha o rumo traçado desde há séculos. Cumprindo o seu programa que João Barrento apelida de “des-hierarquização total do ser” (2004: 284), a autora reforça a ideia de que só através da partilha do mundo o apaziguamento será possível. Por isso, há também desejo por parte dos gatos, que querem carícias "mesmo antes da carne cortada aos bocados", como se lê no excerto.

Este momento de confraternização no limiar da marginalidade distancia-se do banquete do Príncipe de A Restante Vida, realizado após a derrota dos camponeses na batalha de Frankenhausen :

O Príncipe sentou-se com a sua escolta e os seus lacaios, os seus aduladores e os seus animais de recreio, desde o bobo ao grande lebréu. Suas estúpidas perguntas luziam-lhe nos olhos e o seu repasto acabado de comer falava nos seus beiços. (1983a: 34)

Não há aqui cumplicidade, mas hierarquia. Não há utopia, mas obediência. Por isso, os animais de recreio, por isso o lebréu, bem distantes da rebeldia que o gato vadio do 
excerto anterior sugere. Nota-se apenas uma nietzschiana vontade de poder, que a adulação prestada ao Príncipe comprova. Diz Zaratustra: “onde quer que encontrasse aquilo que possui vida, encontrei a vontade de poder, e até na vontade daquele que obedece, encontrei a vontade de ser senhor" (Nietzsche 1885: 139). A imagem repulsiva expressa no excerto de Llansol reforça a negação que a autora faz de um mundo em que os estratos sociais se consolidam pela imposição da força. A (e)utopia llansoliana radicaliza-se pela reprovação de qualquer laivo antropocêntrico.

Através da refeição disponibilizada aos gatos, a narradora encontra um modo de entendimento em que os laços afetivos travam desmandos racionais. Por isso, no livro Onde Vais, Drama-Poesia?, Llansol divide o mundo em duas fações significativas: os que alimentam os gatos vadios e os que os consideram lixo, comentando que "não são dois partidos, apenas humanos e bichos, perdidos de ambos os lados de uma fronteira, sem descortinarmos qual o sentido desse perdido" (2000: 297). É na cumplicidade, na aceitação do convite e na fusão (como a que Parasceve sugere) que a utopia se pode viabilizar. Afinal, para esta autora, razão e bondade não são correlatos perfeitos; pelo contrário, tal associação acaba por ameaçar o próprio homem, ao ponto de divisar o seu apocalipse. Em Llansol, a disponibilização ao outro viabiliza a esperança utópica de um novo mundo.

Também em Raul Brandão se mencionam ofertas, como as que Candidinha recebe das senhores ricas. Não há, porém, sombra de redenção, apaziguamento ou conciliação de vontades. Pelo contrário, afirma esta personagem em $O$ Gebo e a Sombra, "se a gente pede pão, dão-nos escárnio" (Brandão 1923: 110), donde o seu ódio por "todos esses ricos que me fazem bem e me dão de comer" (111). Na sua análise a Sade, Barthes aponta duas interpretações opostas do pão: enquanto "emblema de virtude, de religião, de trabalho, de esforço, de necessidade, de pobreza" (1971: 126), ou enquanto "meio de chantagem: os tiranos escravizam o povo ameaçando tirarem-lhe o pão; é um símbolo de opressão" (ibidem). Na peça brandoniana, este alimento aproxima-se da segunda conotação proposta pelo filósofo francês: sem propriedades redentoras, simboliza apenas a miséria de quem sofre para não morrer à fome.

Ora, ao falar das senhoras que lhe dão esmola, Candidinha revela toda a sua revolta, 
ainda mais nítida perante a tentação pelo dinheiro ao ver a maleta do Gebo com a cobrança do dia: "O que aqui está dentro! (Acaricia a maleta.) Vestidos de seda, lambarices, coisas boas. Ai, deve ser um regalo ter dinheiro, muito dinheiro!” (Brandão 1923: 89). Como os aduladores do Príncipe de Llansol, também Candidinha manifesta uma nietzschiana vontade de poder. Notoriamente, não há vontade de fazer o bem, mas de mandar nos outros. Porém, o poder existe apenas enquanto sonho, já que a realidade é de um "dilúvio universal" (83), como a mesma personagem exprime, ao descrever a tempestade exterior.

Segundo Luís Francisco Rebello, nota-se no texto brandoniano, "em apocalíptica torrente, uma obsidiante problemática, em que a prospecção psicológica, as preocupações sociais e a inquietação metafísica se entrelaçam e misturam" (1986: 31). Por isso, analisar personagens e situações deste autor redunda em perplexidades desafiadoras de leituras unívocas. No entanto, vislumbram-se potenciais chaves de leitura, como o café de $O$ Gebo e a Sombra. Num texto dramático tão conciso, a repetição do ritual de beber uma chávena de café converte-se numa isotopia significativa:

Doroteia (para dentro): Sofia, traz o café.

Candidinha: Ai, tens café?

Chamiço (esfregando as mãos): Aí vem o cafezinho.

Doroteia (para Candidinha): Queres tu uma gota?

Candidinha: Tomo sim, filha. A mim o café faz-me muito mal à palpitação, esta doença que me há-de levar à cova. (Doroteia faz um gesto.) Ai, eu não me iludo. Ainda ontem em casa das Teles: - A minha sepultura está aberta... - Olhem que tenho a roupa apartada pra não incomodar ninguém. (Mudando de tom.) É do forte? Que eu café, só do forte. (Brandão 1923: 81)

Café como veneno, café como alento nas frias noites invernais, bebida que alimenta a união no infortúnio das personagens intervenientes. Trata-se, portanto, de um alimento portador de utopia e, simultaneamente, de um pharmakon aberto a interpretações morais. Também Candidinha, ansiando pelo café, revela o lado negro da sua tragédia pessoal, ao associá-lo à doença e a um desejo de morte: o café causa palpitações; estas poderão matar, mas o café só serve se for forte, logo, causador de mais palpitações. Não há, pois, utopia 
evidente nas vidas destas personagens. Antes, o abismo surge como refrigério de vidas mergulhadas numa noite sem fim.

O ritual do café quente tomado aos serões na casa do Gebo desperta no filho ladrão acabado de regressar repulsa pela curteza de horizontes em que todos vivem. Diz João: "É isto que vocês fazem às noites? Todas as noites? Sempre?..." (83). Esta personagem, diz Gebo, levava "uma vida monstruosa" (67); no entanto, face à miséria de todos, é a sua escolha de vida que acaba por seduzir o próprio pai, que a ela se converte, assim renunciando à honestidade que sempre o caracterizara, ao mesmo tempo que revela o secreto desejo de escapar à miséria. Tal ideia entrevia-se antes do regresso deste filho pouco pródigo, altura em que, no entanto, registava uma réstia de esperança, ao optar pela omissão da verdade:

Gebo (aterrado): Ó, mulher, saber o quê? Que queres tu saber?

Doroteia: Sempre a desgraça, sempre a desgraça!... E eu à espera...

Gebo: Deixa-me... Logo... Vai buscar mais café...

Sofia: Eu vou. (Brandão 1923: 70)

\section{Discernir utopias}

Num curtíssimo texto publicado no jornal Texto \& Letras de 1925, Raul Brandão critica o teatro francês pela sua artificialidade e ligeireza. Ao fazê-lo, este autor renuncia influências de uma arte distanciada do que considera ser o sofrimento humano, por considerar que só este permite a emoção e a empatia entre os homens. Mas há ainda a expressão de um desejo - a sua utopia, talvez: "desejaria que se fizessem peças para o povo, teatro que ele pudesse compreender e amar" (1925: 191), na consciência de que "caminhamos vertiginosamente para um mundo novo, que se está a gerar no tumulto e na dor da nossa época" (ibidem). Descrever a miséria humana é assim, para Raul Brandão, o seu modo de denúncia e de tentativa de reverter uma sociedade que reprova. No entanto, o projeto fica atido a uma narração expressionista que transporta as personagens ao abismo, 
numa externalização da utopia. Não há fim para a fome nas obras de Raul Brandão, pelo que só para além delas será possível uma reconversão efetiva.

Já Llansol, partilhando o descontentamento pela ordem estabelecida, procura uma linha de fuga, que rizomaticamente encontra no animal uma possibilidade nova de regeneração para o próprio homem. Em Parasceve, a criança-ruah, um espírito novo fruto da junção de diferentes componentes humanos e extra-humanos, exclama significativamente: "há caminho!” (2001: 77). A mensagem aglutina um discurso ecologista, ainda que não se esgote nele, na fundação de uma proposta em que todo o planeta se torne num efetivo habitat do vivo. Rente ao chão, desejando comer com os gatos, não há apenas o retrato de uma aspiração à mais absoluta humildade, mas um ensinamento de vida partilhada, utopia que resulta de um mundo humano disforicamente visto como sem esperança e, portanto, tendente à ruína.

Raul Brandão e Maria Gabriela Llansol viveram em décadas diferentes do século XX. 0 primeiro testemunhou o advento da massificação do horror que a primeira guerra mundial produziu. A segunda assistiu às consequências da mais nefasta carnificina perpetrada pelo ser humano, com o genocídio criteriosamente elaborado pelos nazis como símbolo de uma calamidade ética, para além de efetivamente concretizada nos campos de concentração. Llansol assistiu ainda à crise ambiental que, desde os anos de 1970, se tem vindo a acentuar. Tais desmandos exclusivamente humanos não favoreceram posicionamentos otimistas quanto ao ser humano, donde a necessidade de intervenção através da literatura. Nesse sentido, a alimentação, enquanto signo-índice, serve de método diagnóstico: através da sua presença nas obras destes autores, se percebem as carências humanas e, consequentemente, zonas possíveis de atuação com vista ao entendimento e bem-estar coletivo. Afinal, combater a fome e partilhar alimentos incentivam a criação de empatias e só estas vencem as fronteiras que separam os homens.

A refeição como momento de convivialidade, a mesa como metonímia dessa convergência de seres, de vidas: é no espaço de convívio que desejos, aspirações, medos e afetos mais íntimos se desenvolvem e revelam. Platão vê na refeição comum um acontecimento social para promover o entendimento e a concertação de vontades, assim 
fomentando a construção de uma pólis mais justa; Thomas More descreve os jantares de Utopia enquanto momentos de conhecimento e diversão, em que os mais velhos "começam a palestar, em conversas sérias e animadas da melhor disposição" (1516: 101). Contrariamente, Raul Brandão apresenta em O Gebo e a Sombra momentos de intimidade e cumplicidade, mas na miséria.

As refeições comuns servem, para Platão, de fomento a ideais abstratos, ao contrário do que acontece em Llansol. Mesmo em Brandão, não é a ideia abstrata que predomina, mas as emoções e os sentimentos resultantes de uma vida niilista, tanto filosófica como empiricamente, fonte de vidas sem solução. As personagens de $O$ Gebo e a Sombra são assim condicionadas por um ambiente tão fechado quanto sombrio, sem escapatória, a não ser a que Gebo encontra por fim: a vida de crime. Logo, sem uma convivialidade com o diverso, como a proposta pelos gregos, na sua prossecução de uma pólis mais justa e harmoniosa, ou como a interação entre espécies sugerida por Llansol, não há escapatória a uma vida de marginalidade, seja esta pela extrema pobreza, seja pelo crime.

A relação de figuras humanas com gatos, em Llansol, e na de obscuros habitantes de povoações anónimas, em Raul Brandão, cria lugares cuja disforia não elimina um potencial utópico. No escuro da noite, entre a cumplicidade (Llansol) e a tentação (Brandão), entre a partilha (Llansol) e o crime (Brandão), utopia e distopia intersecionam-se, criando pontos de tensão particulares, mesmo quando se trata da introdução do que, sendo um detalhe em obras vastas, corrobora na conceção de visões particulares acerca do homem.

Assim, o olhar distópico de Brandão atravessa a fronteira do grotesco, supera a repulsa, para almejar ao contrário do que se lê: a utopia extrai-se a um discurso apocalíptico. Se a desesperança impera, se a conciliação resulta da queda no mal, $O$ Gebo e a Sombra pode apenas significar que se atingiu um limite e que, portanto, só uma reconversão utópica poderá trazer um novo caminho. É necessário um novo café - não o álcool que o Gebo e o filho sugerem tomar no final - para que haja a esperança de uma nova vida. Mas isso o texto não diz: decorre da leitura e da interpretação da miséria apontada a possibilidade de se aventar um novo mundo.

Há em Maria Gabriela Llansol um messianismo que se nota, por exemplo, no 
caminho proposto pela criança-ruah, enquanto Raul Brandão se atém a uma circularidade, cujo padrão poderá ser a natureza, donde o valor simbólico do inverno ou da árvore despida. Por isso é mais difícil descortinar nele uma verdadeira possibilidade de redenção: o regresso dos mortos que Húmus proclama contraria o caminho salvífico aventado por Llansol em Parasceve.

Se há utopia nestes autores, a crença na sua concretização difere. Aproximam-se pelo enaltecimento dos pobres, tornados modelo de despojamento e de valor espiritual. Porém, em Llansol, os festejos do banquete incentivam a concretização da utopia, ao passo que a fome dos pobres de Raul Brandão remete para a perpetuação de um ciclo de miséria, convertida metonimicamente na precariedade da condição humana. Como as duas faces de Jano, a alimentação revela que, apesar de os cenários distópicos se agigantarem até à mais absoluta irrisão, a utopia subsiste.

\section{Nota}

\footnotetext{
1 Termo adotado por esta autora para designar o que convencionalmente se chama de personagens. A proposta desta forma alternativa prende-se à vontade de a autora lhes conferir uma fluidez de múltiplas consequências, incluindo a libertação das formas até formação de híbridos. É o próprio texto que promove tal movimento, não um exercício de criação estanque de personagens fictícias.
} 


\section{Bibliografia}

Barrento, João (2004), “Um corp'a ler”, in AA. VV. Na Dobra do Mundo. Estudos llansolianos, Lisboa, Mariposa Azual, 281-285.

Barthes, Roland (1999), Sade, Fourier, Loiola, Lisboa, Edições 70 [1971].

Brandão, Raul (1986), Húmus, Lisboa, Círculo de Leitores [1917].

---- (1986) O Gebo e a Sombra, in Teatro, Lisboa, Editorial Comunicação, 59-116 [1923].

---- (1986) "Duas linhas sobre teatro", in Teatro, Lisboa, Editorial Comunicação, 191 [1925a].

---- (1986) “O silêncio e o lume”, in Memórias, tomo II, Lisboa, Relógio D’Água, 39-48 [1925b].

-----(2000) “Balanço à vida”, in Memórias. Vale de Josafat, tomo III, Lisboa, Relógio D’Água, $35-48$ [1933].

Derrida, Jacques (1997) "Fé e saber. As duas fontes da «religião» nos limites da simples razão", in AAVV. A Religião, Lisboa, Relógio d'Água, 9-93 [1996].

Deleuze, Gilles (1994) Nietzsche, Lisboa, Edições 70 [1965].

Eiras, Pedro (2005), Esquecer Fausto. A fragmentação do sujeito em Raul Brandão, Fernando Pessoa, Herberto Helder e Maria Gabriela Llansol, Porto, Campo das Letras.

Jackson, Michael/Grace, Damien (2014), “Dinner in Utopia: Why did Plato Propose 'Amazing and Frightening' Meals in Common?", in A. VV. Spaces of Utopia, 2nd series, no. 3, 9-26.

Llansol, Maria Gabriela (1999), O Livro das Comunidades, Lisboa, Relógio D’Água [1977]. --(2001), A Restante Vida, Lisboa, Relógio D’Água [1983].

--(2000), Onde Vais, Drama-Poesia?, Lisboa, Relógio D’Água.

--(2001), Parasceve. Puzzles e ironias, Lisboa, Relógio D’Água.

Lopes, Silvina Rodrigues (1988), Teoria da Des-Possessão (Ensaios sobre textos de Maria N. 36 - 06/ 2017 | 227-247 - ISSN 2183-2242 | http:/dx.doi.org/10.21747/21832242/litcomp36a13 246 
Gabriela Llansol, Lisboa, Black Sun Editores.

More, Thomas (1985), Utopia, Lisboa, trad. José Marinho, Guimarães Editores [1516].

Nietzsche, Friedrich (2004), Assim Falava Zaratustra, Lisboa, Guimarães Editores [1885].

Platão (1961), Laws, Cambridge / Massachusets, Harvard University Press.

Rebello, Luiz Francisco (1986), “Um teatro de dor e de sonho. Estudo introdutório”, in Raul Brandão, Teatro, Lisboa, Editorial Comunicação, 7-48.

Reynaud, Maria João (2000), Metamorfoses da Escrita. Húmus, de Raul Brandão, Porto Campo das Letras.

Sargent, Lymen Tower (2005) "The necessity of utopian thinking: Cross-national perspective", in AA.VV. Thinking Utopia. Steps into other worlds, ed. Jörn Rüsen / Michael Fehr / Thomas W. Rieger, New York/Oxford, Berghahn Books, 1-14.

Lígia Bernardino concluiu, na Faculdade de Letras da Universidade do Porto, em 2014, o doutoramento em Literaturas e Culturas Românicas - Especialidade de Literatura Portuguesa, com a tese denominada Limiares do Humano. Estudo sobre Jorge de Sena, Maria Gabriela Llansol e Gonçalo M. Tavares. Exerce funções de docente. Ao longo da sua carreira profissional, envolveu-se em projetos na área do ensino, da tradução, da lexicografia e do jornalismo. Desenvolve estudos de literatura comparada e literatura portuguesa contemporânea. 